\title{
BARTONELLOSIS IN CATS AND ITS ROLE IN PUBLIC HEALTH
}

\author{
[Bartonelose em gatos e sua importância na saúde pública]
}

\author{
Camila Lopes Riberio de Almeida ${ }^{{ }^{*}}$; Veronica J. Babo-Terra ${ }^{2}$ \\ 1 Acadêmica de Medicina Veterinária da FAMEZ/UFMS. Av. Filinto Muller, 2443, Campo Grande, MS. \\ 2 Profa Dra. de Clínica Médica e Terapêutica de Pequenos Animais da FAMEZ/UFMS. Av. Filinto Muller, 2443, Campo \\ Grande, MS.
}

\begin{abstract}
The genus Bartonella is composed of various zoonotic species that cause important diseases, usually in immunosuppressed individuals. The main reservoirs are domestic felines and these do not often present any clinical signs, but are usually in a state of intermittent bacteremia. So that, there is a potential risk of disease dissemination as well as transmission of the agent to other cats, mainly by the feces of fleas, and to human beings through the bite or scratch of the animal. The aim of this study was to review the occurrence of Bartonellosis in humans and cats, as well as the major zoonotic, clinical, laboratorial and treatment aspects. Further studies are necessary in order to gather more knowledge about the disease and its prevention. However, we have to point out that, since the definitive diagnosis and treatment in cats are still uncertain and controversial issues, the best way to control the disease is so far through the animal vector control, by the adoption of a correct and effective protocol of flea control, and by preventing bites and scratches in immunosuppressed people and professionals who directly deal with cat.
\end{abstract}

Keywords: Feline, humans, zoonosis.

RESUMO - O gênero Bartonella é composto por várias espécies que possuem caráter zoonótico e que causam doenças importantes, geralmente em pessoas imunossuprimidas. Os principais reservatórios são os gatos domésticos sendo que estes geralmente não apresentam sintomatologia, mas encontram-se, muitas vezes, em situação de bacteremia intermitente, de forma que existe o risco potencial de disseminação da doença e transmissão do agente para outros gatos, principalmente por meio das fezes das pulgas, e para o próprio homem, através da mordida ou da arranhadura do animal. O objetivo do estudo foi revisar a ocorrência de Bartonelose em humanos e em felinos, bem como principais aspectos zoonóticos, clínicos, laboratoriais e terapêuticos. Mais estudos precisam ser realizados com o intuito de aprofundar os conhecimentos referentes à doença bem como sua prevenção, porém, o que se deve ter em mente é que como o diagnóstico definitivo da enfermidade e o tratamento em gatos ainda são assuntos polêmicos e muito duvidosos, a melhor maneira de controlar a doença, até o momento, é por meio do controle dos vetores no animal, a partir da adoção de um protocolo de controle de pulgas correto e eficaz, bem como a prevenção de mordidas e arranhões em pessoas imunossuprimidas e profissionais que lidam diretamente com felinos.

Keywords: Felino, homem, zoonose.

\section{INTRODUCTION}

A new organism, Rochalimaea henselae, was discovered in 1992 (Regnery et al., 1992a,b) and in the following year, Brenner et al. (1993) proposed the unification of genera Rochalimaea e Bartonella and, thereby, the bacterium was renamed Bartonella henselae. Since then, hundreds of articles have been published regarding treatment, clinical signs and epidemiology of the infection in humans and animals, especially in the domestic cat.

\footnotetext{
* Autor para correspondência: milalopes@hotmail.com
}

The genus Bartonella is constituted by various zoonotic species that represent emerging infectious diseases in Brazil and around the world (Chomel et al., 2006; Breitschwerdt, 2008; Mogollon-Pasapera, 2009). Among them, Bartonella henselae is the most studied and reported to cause disease in humans (Boulouis et al., 2005; Guptill, 2010). It's characterized as Gram negative fastidious bacillus that adhere to endothelial cells and erythrocytes after biting and/or cat-scratch, affecting mainly young animals less than a year of age (Breitschwerdt et al., 2000; Chomel et al., 2004; Boulouis et al., 2005). 
The most emerging diseases caused by Bartonella species were first described in humans and later in cats and dogs. Some studies demonstrated that pet cats serve as the main persistent reservoir host that shows prolonged asymptomatic bacteremia to five Bartonella species: Bartonella henselae, Bartonella clarridgeiae, Bartonella koehlerae, Bartonella weissii and Bartonella elizabethae (Kordick et al., 1999; Breitschwerdt \& Kordick, 2000; Breitschwerdt, 2008).

The aim of this study was to review the occurrence of Bartonellosis in humans and cats, as well as the major zoonotic, clinical, laboratorial and treatment aspects because, according to Kikuchi et al. (2002), although underestimated, the disease has great importance in Brazil and other countries.

\section{REVIEW}

\section{BARTONELLOSIS IN PET CATS}

\section{Occurrence of the agent in cats in Brazil and other countries}

In a study conducted in Northern California, researchers found a high prevalence of Bartonella henselae infections in young cats (Chomel et al., 1995). The bacteria was isolated from blood of $39,5 \%(81 / 205)$ of the cats, which were subsequently confirmed by the PCR technique. Also $81 \%$ $(166 / 205)$ of the animals had antibodies against the microorganism.

Another study conducted in the United States (Guptill et al., 2004), demonstrated seropositivity, using the enzyme linked immunosorbent assay (ELISA), in $51 \%(138 / 271)$ of the cats, with the highest prevalence been detected in Florida (67\%), when compared to other three studied regions (Southern California, metropolitan regions of Chicago and Washington).

In 2005, the first study about the prevalence of $B$. henselae in cats from Spain was conducted (Pons et al., 2005). From the blood samples of 100 cats, culture was positive to seven and subsequent differentiation among species was performed by PCR test, which showed the presence of $B$. henselae. Subsequently, through the Indirect Immunofluorescence test, antibodies against the bacteria were found in $29,6 \%$ (34/115) of the cats.
In a research conducted in France, blood samples were collected from 94 stray cats. The material was cultivated and results showed a prevalence of $53 \%$ (50/94) of Bartonella spp. Then, using the PCR test on the growing material, the authors identified $70 \%$ $(35 / 50)$ of positivity to $B$. henselae and $30 \%(15 / 50)$ related to $B$. clarridgeiae. Therefore, the importance of the cat as a reservoir for the bacteria was highlighted in this study (Heller et al., 1997).

In Brazil, recent research in Rio de Janeiro state (Souza et al., 2010) demonstrated high prevalence, through molecular biology, of Bartonella spp. in pet cats that lived in a shelter, in which from 37 animals studied, $36(97,3 \%)$ were positive for the genus Bartonella.

In another analysis (Crissiuma et al., 2011) in the same state, 40 healthy cats were tested showing 17 $(42,5 \%)$ positive cases for Bartonella DNA species in the blood, detected by PCR test, and 19 (47,5\%) presenting antibodies against the microorganism in the serum, through the Immunofluorescence test.

Another similar research carried out in Brazil, in Rio Grande do Sul state, detected Bartonella spp. in $17,02 \%$ (8/47) of the samples collected from 47 cats aged less than 12 months, using PCR. From the phylogenetic analysis by the DNA sequencing of the eight positive samples, five corresponded to $B$. henselae and three to B. clarridgeiae (Staggemeier et al., 2010).

A recent research using PCR (Braga et al., 2012) in 200 cats revealed nine cats $(4,5 \%)$ positive for the genus Bartonella. In the same year, a study conducted in Sao Paulo, Jaboticabal city, revealed positivity of $4,3 \%$ among healthy cats, using PCR method (Bortoli et al., 2012).

\section{Transmission among cats}

The primary way of transmission among cats is by fleas, especially Ctenocephalides felis. These fleas ingest the microorganism during blood meal in infected cats and, so that viable bacteria can be found in feces of the vector. The transmission to the vector occurs by contact with fleas or through their remaining feces in the animal's coat which contain live bacteria for at least nine days (Chomel et al., 1996).

In a study conducted by Foil et al. (1998), cats became bacteremic after intradermal inoculation of 
the contaminated flea feces. Thus, the infection of other cats and possibly humans may happen at the moment the cat scratches due to nails contamination by flea feces.

Studies have shown that an infected cat and an uninfected one can live together freely, as long as flea infestation doesn't occur; otherwise, transmission between cats happens easily. Besides, it was impossible to detect, in an free fleas environment, venereal transmission among bacteremic animals and among the queen and her kittens during the pregnancy and neonatal period (Abbot et al., 1997; Guptill et al., 1997; Guptill et al., 1998). However, another study showed the possibility of transmiting the agent $B$. henselae by blood transfusions (Magalhães et al., 2008).

Researchers also revealed the presence of bacterial DNA in ticks and hematophagous flies, showing that the role of other vectors in transmitting Bartonellosis should be further explored (Sanogo et al., 2003; Chung et al., 2004).

\section{Clinical signs}

Bartonellosis in cats is a controversial subject, once the majority of animals remain asymptomatic (Kordick et al., 1997; AAFP, 2006). However, when cats show any symptoms, it is difficult to associate them to the disease itself as these may be nonspecific and mimic other diseases such as Feline Herpesvirus type 1, Feline Calicivirus, Feline Immunodeficiency virus and Feline Leukemia Virus (Quimby et al., 2007; Dowers et al, 2010). Under these circumstances, these disorders can mislead diagnosis, complicate treatment and prevention of transmission to other cats and humans.

Symptoms in cats, when they exist, are usually associated to upper and lower urinary tract infections, stomatitis and lymphadenopathy (Chomel et al., 2006). However, some cases of uveitis and endocarditis have been associated, by molecular biology, to Bartonella henselae infection (Lappin \& Black, 1999; Chomel et al., 2003; Ketring et al., 2004; Stiles, 2011).

\section{Treatment}

There is no certainty of antimicrobial efficacy for feline bartonellosis treatment, and there is a risk of continuous re-infection due to absence of immunologic memory to the agent, in case of continuous flea exposure (Kordick et al., 1997; AAFP, 2006).

Treatment is considered to be difficult and should last for at least four to six weeks and often proves to be ineffective, due to bacterial intermittent nature and intracellular characteristic (Holf, 1991; Regnery et al., 1996; Kordick et al., 1997).

In a study, Kordick et al. (1997) evaluated doxycycline and enrofloxacin effectiveness in treating cats known to be infected, and reported difficulty in achieving good results by choosing a specific treatment protocol, due to the high bacteremic fluctuation during the natural course of the disease. However, enrofloxacin $(3,5-11,4 \mathrm{mg} / \mathrm{kg}$, orally, twice a day for 28 days) apparently eliminated bacteremia from five of a total of seven cats. On the other hand, enrofloxacin is contraindicated in doses higher than $5 \mathrm{mg} / \mathrm{kg}$, because it may cause retina degeneration and blindness in some cats (Wiebe, 2002). Doxycycline also shows to be effective in treating the disease, when used in $6,9-12,8 \mathrm{mg} / \mathrm{kg}$, orally, twice a day for 14 days or $4-10,4 \mathrm{mg} / \mathrm{kg}$, orally, twice a day for 28 days.

In the same study, the authors suggest that, due to the risk of developing bacterial resistance, treatment recommendation of the cat should only be considered when the owner is immunocompromised or as an alternative when the animal is at risk of euthanasia.

According to the American Association of Feline Practitioners - AAFP (2006), since there is no report of a proven effective drug to treat cats, some medicines used in humans, such as fluroquinolones and azithromycin shouldn't be prescribed for bacterial infections in cats if there are other alternatives to treatment. Thus, doxycycline $(10 \mathrm{mg} / \mathrm{kg}$, orally, twice or once a day) or amoxicillin-clavulanate $(22 \mathrm{mg} / \mathrm{kg}$, orally, twice a day) should be the first choice medications. Besides treatment, flea control is essential and, since symptomatic animals are probably in bacteremia, additional care such as avoiding bites and scratches should be taken.

\section{BARTONELLOSIS IN HUMANS}

\section{Zoonotic importance}


Bartonella henselae is known as the main causative agent of Bacillary Angiomatosis, Bacillary Peliosis and cat scratch disease (CSD) in humans. CSD cause classic symptoms of regional lymphadenopathy, fever, malaise, headache and papules that turn into pustules at the inoculation site (Chomel et al., 1995; Kordick \& Breitschwerdt, 1995; Breitschwerdt \& Kordick, 2000; Guptill et al., 2000; Boulouis et al., 2005).

In most cases, the disease is self-limiting in immunocompetent individuals, however, in immunosuppressed people, such as children or HIVpositive individuals, the disease may have a fatal outcome and antibiotic therapy should be required for a long term. In 5 to $9 \%$ of the patients presenting CSD, who face some immunological deficiency, there may be atypical manifestations of disease such as encephalitis, endocarditis, hemolytic anemia, liver and spleen enlargement, glomerulonephritis, pneumonia,intermitent bacteremia, eye injuries, osteomyelitis and a possible change in reproductive performance (Breitschwerdt et al., 2010; Oliveira et al., 2004; Rolain et al., 2004; Chomel et al., 2006).

\section{Transmission to humans}

The real importance of the flea as a vector to humans is unknown, but since the presence of fleas is essential for the maintenance of infection in cats, there it is a strong correlation between high flea infestation in cats and high number of cases of the disease identified in humans (Chomel et al., 1996; Breitschwerdt \& Kordick, 2000).

The primary mode of transmission is through the contaminated cat nails with flea feces as well as their teeth (Breitschwerdt \& Kordick, 2000). However, although there is no scientific evidence, ticks can represent a risk of transmission of $\mathrm{B}$. henselae since the agent was detected in Ixodes ricinus collected in humans (Sanogo et al., 2003).

In addition, a study in the United States showed the possibility of intrauterine transmission or during the cesarean procedure of $\mathrm{B}$. henselae from the mother to her child (Breitschwerdt et al., 2010).

\section{Occurrence in humans in Brazil and in other countries}

In Brazil, a study conducted in Piau city, Minas Gerais state, detected seropositivity to $B$. henselae in 60 individuals $(13,7 \%)$ in a total of 437 (Costa et al., 2005). Another research in Brazil, in Rio de Janeiro city (Lamas et al., 2010), serologically evaluated HIV-infected individuals and samples from a blood bank. IgG antibodies to Bartonella spp. were found in $38,4 \%$ of the patients (48/125) and in $34,4 \%$ $(43 / 125)$ of the blood donors. It's a high number since some studies have proven that microorganisms of the Bartonellae family are able to survive in blood samples stored for at least 35 days, showing the possible transmission by blood transfusion (Reine, 2004).

Moreover, in the same study (Lamas et al., 2010), $65 \%(13 / 20)$ of the patients who reported ownership of cats in home were seropositives versus $34 \%$ $(22 / 65)$ of those who didn't report animal contact so that the authors found a close relationship among breeding cats and possible infection of Bartonella spp.

In a case reported by Breitschwerdt et al. (2011), in the United States, antibodies against B. koehlerae as well as the agent itself were detected by PCR test, in a 18 year- old woman who had presented progressive abnormal neurocognitive signs for four years, showing signs of depression, anxiety, headache, muscle spasms, interphalangeal joint stiffness, decreased peripheral vision, decreased tactile sensation and hallucinations. The patient was treated for a long period and there was improvement in clinical status.

Another study in the United States revealed that from 49 patients presenting Bacillary Angiomatosis and/or Bacillary Peliosis, 26 were infected to $B$. henselae and found to be epidemiologically associated to cats or fleas exposure (Koehler et al., 1997).

In a report described by Murinello et al. (2010), in Portugal, a 44 year-old woman was diagnosed with CSD after being scratched by her young and newly acquired cat. The inoculation site had swollen up, with the presence of papules, crusting, pain and regional lymphadenopathy. The diagnosis was confirmed through Indirect Immunofluorescence serologic test and PCR from the biopsy of the axillary node. Also, agent detection was possible by molecular biology from the blood of the patient's cat. It's noteworthy in this context, the importance of tests such as PCR to quick and accurate confirmation of the disease as early as possible.

A study carried out in Rio de Janeiro city described two probable cases and 11 confirmed cases of bacillary angiomatosis, by histophatologic examination, in people presenting Human Immunodeficiency Virus (HIV-1) from five public referral hospitals in treatment of AIDS (Gazineo et 
al., 2001). The most frequent clinical signs observed were cutaneous lesions, fever, anorexia, liver enlargement and lymphadenophaty, and a case of Hepatic Bacillary Peliosis was detected in postmortem examination in one of the patients. Bacillary peliosis is characterized by vascular proliferation lesions in addition to capillary dilatation, formation of cavernous spaces filled with blood in the liver, spleen or bone marrow. Seven patients died due to a probable cause of bacillary angiomatosis.

In a case reported by Velho et al. (2006), in Brazil, a woman diagnosed with AIDS presented symptoms suggestive of Bacillary Angiomatosis, such as papular and papulo-nodular lesions, hemorrhagic and pain throughout the body as well as fever and a history of living with multiple cats. The disease was detected by pathological examination, characterized by the authors as an important diagnostic method, especially when serology is not available. The pathological findings were basically atrophic epidermis, dermis with numerous capillaries lined by endothelial edematous cells, cellular atypia, neutrophilic infiltrate and the presence of innumerous bacilli. In addition to the laboratory results, clinical findings and successful therapy with tetracycline were taken together to achieve the definitive diagnosis.

Researchers concluded that we still don't know enough about the real importance of this infection, but it's certain that Bartonella are potentially fatal. Thus, further research must be conducted in order to gain more information about the issue (Velho et al., 2006).

In case related by Lamas et al. (2007), in Rio de Janeiro city, a man with a history of cardiopathy, was complaining of fatigue and dyspnea after light exercise in the last four months and, by anamnesis, it was found he had been exposed to a young cat a few months before the onset of signs. The histopathology of the excised native aortic valve revealed a vegetative shape suggestive of bacterial endocarditis. Culture of blood and the valve material was performed, as well as molecular biology and Indirect Immunofluorescence Serologic test, in attempt to detect antibodies against $B$. henselae. Despite of the negative results of the culture and PCR test, the diagnosis was established based on the high $\mathrm{IgG}$ titer (1:4096) before the beginning of treatment with antibiotics, and a lower titer 14 months after treatment (1:512).

Lamas et al. (2007) concluded that the possibility of the occurrence of many endocarditis cases caused by Bartonella species exists, but they are not considered by a great number of doctors. In addition, there is little information from reference laboratories about laboratory diagnostic methods that can be used to help on definitive diagnosis of this agent.

In Brazil, Minas Gerais state, Souza (2011) reported a case of a 79 year-old woman presenting cervical ulcerated adenopathy after close contact with cats. According to the author, the diagnosis was suggestive of CSD after specific findings on histopathology, clinical signs, therapy response and exclusion of other diseases that can cause similar symptoms.

\section{The main laboratory diagnostic methods used for Bartonellosis}

Despite of the fact that some authors consider the Indirect Immunofluorescence Serological test as the gold standard for detecting Bartonella species infection (Lamas et al., 2008), other researchers report that there is no gold standard method to detect it (AAFP, 2006; Velho et al., 2006). However, the negative culture, PCR and serological results strongly indicate that the animal is not a potential source of transmission of the bacteria to other cats and humans (AAFP, 2006).

In general, the diagnosis can be performed basically through the culture of blood or tissue samples, by detection of specific antibodies in serum, cerebrospinal fluid or aqueous humor and/or by detection of specific DNA fragment through Polymerase Chain Reaction (PCR) from tissue samples and body fluids (AAFP, 2006).

The isolation of Bartonella species indicates current infection, however, despite of the greater sensitivity of blood culture versus genetic detection techniques (Zanutto et al., 2001), the main limitations to perform this test are the necessity of specialized laboratories and a long period to obtain the results, since these microorganisms are fastidious, grow slowly and the material can't be dropped off before 56 days, so that it doesn't apply to the routine of most clinical pathology laboratories (Breitschwerdt \& Kordick, 2000; Fenollar and Raoult, 2004; AAFP, 2006; Velho et al., 2006).

The serological tests such as ELISA and Indirect Immunofluorescence have been widely used for the diagnosis of Bartonella species because they are fast and affordable. However, positive results are not able to distinguish between current infection or simple exposure to the agent, and they can't 
differentiate the infecting species. In addition, negative results don't rule out infection (AAFP, 2006; Velho et al., 2006). Moreover, serological tests may be limited by the possibility of crossreactivity among different species of bacteria as well as other agents like Coxiella and Chlamydia (La Scola \& Raoult, 1996; Maurin et al., 1997; Costa et al., 2005).

PCR requires specialized laboratories and its performance can be expensive, but the results are obtained faster than by culture and isolation and allow the discrimination among species, in opposite to serological tests. For these reasons, PCR is recommended in order to diagnose exposure to the agent and infection of cats with Bartonella spp. (Fenollar \& Raoult, 2004; AAFP, 2006; Souza et al., 2010).

According to the AAFP (2006), diagnosis can be achieved when there are consistent and reported clinical signs related to feline Bartonellosis in addition to the exclusion of other diseases that show similar clinical signs, a positive laboratory test (culture, PCR or serology) and therapy response when recommended drugs are used.

However, even when these criteria are met, due to tests limitations and the wide spectrum efficacy achieved with recommended treatments, which may mess up the diagnosis of other diseases with similar symptomatology, doctors may face difficulties in obtaining the definitive diagnosis (AAFP, 2006).

\section{FINAL CONSIDERATIONS}

Thus, as higher prevalences of the disease are found in tropical countries (Boulouis et al., 2005), further studies are mandatory in Brazil in order to adopt prevention and control measures.

Besides, studies in order to confirm Bartonella spp. infections in pet cats are extremely important, considering that these are important zoonotic and occupational diseases, mainly in immunocompromised people and Veterinarians.

Once diagnosis and treatment of the disease in cats are complex and there is no vaccine available, it is essential that vector control measures are adopted, by periodically using effective flea control estrategies. Cats must not receive blood transfusions from an unknown cat or from those that are known to be infected with Bartonella spp. In addition, bites and scratches must be avoided, especially by immunocompromised people and professionals who deal directly with cats.

\section{REFERÊNCIAS}

AAFP - Association of Feline Practitioners. 2006. Panel report on diagnosis, treatment, and prevention of Bartonella species infections. Journal of Feline Medicine and Surgery. 8:213-226.

ABBOTT, R.C., CHOMEL, B.B., KASTEN, R.W., FLOYDHAWKINS,K.A., KIKUCHI, Y., KOEHLER, J.E. \& PEDERSEN, N.C. 1997. Experimental and natural infection with Bartonella henselae in cats. Comparative Immunology Microbiology and Infectious Disease. 20(1):41-57.

BOULOUIS, H.J., CHANG, C., HENN, J.B., KASTEN, R.W. \& CHOMEL, B.B. 2005. Factors associated with the rapid emergence of zoonotic Bartonella infections. Veterinary Research. 36:383-410.

BORTOLI, C.P.; ANDRÉ, M.R.; SEKI, M.C.; PINTO, A.A.; MACHADO, S.T.Z.; MACHADO, R.Z. Detection oh hemoplasma and Bartonella species and co-infection with retroviruses in cats subjected to a spaying/neutering program in Jaboticabal, SP, Brazil. Revista Brasileira de Parasitologia Veterinária. 21(3):219-223.

BRAGA, M.S.C.O.; DINIZ, P.P.V.P.; ANDRÉ, M.R.; BORTOLI, C.P.; MACHADO, R.Z. 2012. Molecular characterisation of Bartonella species in cats from São Luís, state of Maranhão, north-eastern Brazil. Memórias do Instituto Oswaldo Cruz. 107(6):772-777.

BREITSCHWERDT, E.B. \& KORDICK, D.L. 2000. Bartonella infection in animals: carriership, reservoir potential, pathogenicity, and zoonotic potential for human infection. Clinical Microbiology Reviews. 13:428-438.

BREITSCHWERDT, E.B. 2008. Feline bartonellosis and cat scratch disease. Veterinary Immunology and Immunopathology.. 15:167-171.

BREITSCHWERDT, E.B., MAGGI, R.G., FARMER, P. \& MASCARELLI, P.E. 2010. Molecular Evidence of Perinatal Transmission of Bartonella vinsonii subsp. berkhoffii and Bartonella henselae to a Child. Journal of Clinical Microbiology. 48(6):2289-2293.

BREITSCHWERDT, E.B., MASCARELLI, P.E., SCHWEICKERT, L.A., MAGGI, R.G., HEGARTY, B.C., BRADLEY, J.M. \& WOODS, C.W. 2011. Hallucinations, Sensory Neuropathy, and Peripheral Visual Deficits in a Young Woman Infected with Bartonella koehlerae. Journal of Clinical Microbiology.49(9):3415-3417. 
BRENNER, D.J., O’CONNOR, S.P., WINKLER, H.H. \& STEIGERWALT, A.G.1993. Proposals to Unify the Genera Bartonella and Rochalimaea, with Descriptions of Bartonella quintana comb. nov., Bartonella vinsonii comb. nov., Bartonella henselae comb. nov. and Bartonella elizabethae comb. nov. and to Remove the Family Bartonellaceae from the Order Rickettsiale. International Journal of Systematic Bacteriology. 43(4):777-786.

CHOMEL, B.B., ABBOTT, R.C., KASTEN, R.W., FLOYD-HAWKINS, K.A., KASS, P.H., GLASER, C.A., PEDERSEN, N.C. \& KOEHLER, J.E. 1995. Bartonella henselae prevalence in domestic cats in California: risk factors and association between bacteremia and antibody titers. Journal of Clinical Microbiology.33:2445-2450.

CHOMEL, B.B., KASTEN, R.W., FLOYD-HAWKINS, K., CHI, B., YAMAMOTO, K., ROBERTS-WILSON, J., GURFIELD,A.N., ABBOTT, R.C., PEDERSEN, N.C. \& KOEHLER, J.E. 1996. Experimental transmission of Bartonella henselae by the cat flea. Journal of Clinical Microbiology. 34:1952-1956.

CHOMEL, B.B., WEY, A.C., KASTEN, R.W., STACY, B.A. \& LABELLE, P. 2003. Fatal Case of Endocarditis Associated with Bartonella henselae Type Infection in a Domestic Cat. Journal of Clinical Microbiology. 41(11):5337-5339.

CHOMEL, B.B., BOULOUIS, H.J. \& BREITSCHWERDTE.B. 2004. Cat scratch disease and other zoonotic Bartonella infections. Journal of the American Veterinary Medical Association. 224 (8):12701279.

CHOMEL, B.B., BOULOUIS, H.J., MARUYAMA, S. \& MOLIA, S. 2006. Bartonella spp. in pets and effect on human health. Emerging Infectious Diseases. 12(3):389394.

CHUNG, C.Y., KASTEN, R.W., PAFF, S.M., VAN HORN, B.A., VAYSSIER-TAUSSAT, M., BOULOUIS, H.J. \& CHOMEL, B.B. 2004. Bartonella spp. DNA associated with biting flies from California. Emerging Infectious Diseases. 10,(7):1311-1313.

COSTA, P.S.G., BRIGATTE, M.E. \& GRECO, D.B. 2005. Antibodies to Rickettsia rickettsii, Rickettsia typhi, Coxiella burnetii, Bartonella henselae, Bartonella quintana, and Ehrlichia chaffeensis among healthy population in Minas Gerais, Brazil. Memórias do Instituto Oswaldo Cruz. 100(8):853-859.

CRISSIUMA, A., FAVACHO, A., GERSHONY, L., ALMEIDA, F.M., GOMES, R., MARES-GUIA, A., ROZENTAL, T., BARREIRA, J., LEMOS, E. \& LABARTHE, N. 2011. Prevalence of Bartonella species DNA and antibodies in cats (Felis catus) submitted to a spay/neuter program in Rio de Janeiro, Brazil. Short communication, Journal of Feline Medicine and Surgery. 13:149-151.
DOWERS, K.L., HAWLEY, J.R., BREWER, M.M., MORRIS, A.K., RADECKI, S.V. \& LAPPIN, M.R. 2010. Association of Bartonella species, feline calicivirus, and feline herpesvirus 1 infection with gingivostomatitis in cats. Journal of Feline Medicine and Surgery. 12(4):314-321.

FENOLLAR, F. \& RAOULT, D. 2004. Molecular genetic methods for the diagnosis of fastidious microorganisms. Acta Pathologica, Microbiologica et Immunologica Scandinavica. 112: 785-807.

FOIL, L., ANDRESS, E., FREELAND, R.L., ROY, A.F., RUTLEDGE, R., TRICHE, P.C.; O'REILLY, K.L. 1998. Experimental infection of domestic cats with Bartonella henselae by inoculation of Ctenocephalides felis (Siphonaptera: Pulicidae) feces. Journal of Medical Entomology. 35:625-628.

GAZINEO, J.L.D., TROPE, B.M., MACEIRA, J.P., MAY, S.B., COELHO, J.M.C.O., LAMBERT, J.S. \& NOGUEIRA, S.A. 2001. Bacillary angiomatosis: description of 13 cases reported in five reference centers for aids treatment in Rio de Janeiro, Brazil. Revista do Instituto de Medicina Tropical de São Paulo. 43(1):1-6.

GUPTILL, L., SLATER, L., WU, C.-C., LIN, T.L., GLICKMAN, L.T., WELCH, D.F. \& HOGENESCH, H. 1997. Experimental infection of young specific pathogenfree cats with Bartonella henselae. Journal of Infectious Disease. 176:206-216.

GUPTILL, L., SLATER, L., WU, C.-C., LIN, T.L., GLICKMAN, L.T., WELCH, D.F., TOBOLSKI, J. \& HOGENESCH, H. 1998. Evidence of reproductive failure and lack of perinatal transmission of Bartonella henselae in experimentally infected cats. Veterinary Immunology and Immunopathology. 65:177-189.

GUPTILL, L., WU, C.C., GLICKMAN, L., TUREK, J., SLATER, L. \& HOGENESCH, H. 2000. Extracellular Bartonella henselae and artifactual intraerythrocytic pseudoinclusions in experimentally infected cats. Veterinary Microbiology.76:283-290.

GUPTILL, L., WU, C.-C., HOGENESCH, H., SLATER, L.N., GLICKMAN, N., DUNHAM, A., SYME, H. \& GLICKMAN, L. 2004. Prevalence, risk factors, and genetic diversity of Bartonella henselae infections in pet cats in four regions of the United States. Journal of Clinical Microbiology, 42:(2)652-659.

GUPTILL, L. 2010. Bartonellosis. Veterinary Microbiology. 140:347-359.

HELLER, R., ARTOIS, M., XEMAR, V., BRIEL, D., GEHIN, H., JAULHAC, B., MONTEIL, H. \& PIEMONT, Y. 1997. Prevalence of Bartonella henselae and Bartonella clarridgeiae in Stray Cats. Journal of Clinical Microbiology. 35(6):1327-1331. 
HOLF, H. 1991. Intracellular microorganisms: A particular problem for chemotherapy. Infection. 19(4):193-194.

KETRING, K.L., ZUCKERMAN, E.E., \& HARDY, W.D. 2004. Bartonella: a new etiological agent of feline ocular disease. Journal of the American Animal Hospital Association. 40:6-12.

KIKUCHI, E., MARUYAMA, S., SAKAI, T., TANAKA, S., YAMAGUCHI, F., HAGIWARA, T., KATSUBE, Y., MIKAMI, T. 2002. Serological investigation of Bartonella henselae infections in clinically cat-scratch disease-suspected patients, patients with cardiovascular diseases, and healthy veterinary students in Japan. Microbiology and Immunology. 46:313-316.

KOEHLER, J.E., SANCHEZ, M.A. \& GARRIDO, C.S. 1997. Molecular epidemiology of Bartonella infections in patients with bacillary angiomatosis-peliosis. The new England Journal of Medicine. 337(26):1876-1883.

KORDICK, D.L. \& BREITSCHWERDT, E.B. 1995. Intraerythrocytic presence of Bartonella henselae. Journal of Clinical Microbiology. 33:1655-1656.

KORDICK, D.L., PAPICH, M.G., \& BREITSCHWERDT, E.B. 1997. Efficacy of Enrofloxacin or Doxycycline for Treatment of Bartonella henselae or Bartonella clarridgeiae Infection in Cats. Antimicrobial Agents and Chemotherapy. 41(11):2448-2455.

KORDICK, D.L., BROWN, T.T., SHIN, K. \& BREITSCHWERDT, B. 1999. Clinical and pathologic evaluation of chronic Bartonella henselae or Bartonella clarridgeiae infection in cats. Journal of Clinical Microbiology. 37:1536-1547.

LA SCOLA, B. \& RAOULT, D. 1996. Serological crossreactions between Bartonella quintana, Bartonella henselae and Coxiella burnetii. Journal of Clinical Microbiology. 34(9):2270-2274.

LAMAS, C.; FAVACHO, A.; RAMOS, R.G., SANTOS, M.S., FERRAVOLI, G.I., WEKSLER, C., ROZENTAL, T., BÓIA, M.N. \& LEMOS, E.R.S. 2007. Bartonella native valve endocarditis: The First Brazilian Case Alive and Well. The Brazilian Journal of Infectious Disease. 11(6):591-594.

LAMAS, C.; CURI, A.; BÓIA, M.N. \& LEMOS, E.R.S. 2008. Human bartonellosis: seroepidemiological and clinical features with an emphasis on data from Brazil- A Review. Memórias do Instituto Oswaldo Cruz. 103(3):221-235.

LAMAS, C.C., MARES-GUIA, M.A., ROZENTAL, T., MOREIRA, N., FAVACHO, A.R.M., BARREIRA, J., GUTERRES, A., BÓIA, M.M. \& LEMOS, E.R.S. 2010. Bartonella spp. infection in HIV positive individuals, their pets and ectoparasites in Rio de Janeiro, Brazil:
Serological and molecular study. Acta Tropica. 115:137141.

LAPPIN, M.R. \& BLACK, J.C. 1999. Bartonella spp. Infection as a possible cause of uveitis in a cat. Journal of the American Veterinary Medical Association. 214(8):1205-1207.

MAGALHÃES, R.F., PITASSI, L.H.U., SALVADEGO, M., MORAES, A.M., BARJAS-CASTRO, M.L., VELHO, P.E.N.F. 2008. Bartonella henselae survives after the storage period of red blood cell units: is it transmissible by transfusion? Transfusion Medicine. 18(5):287-291.

MAURIN, M., ETIENNE, J. \& RAOULT, D. 1997. Serological cross-reactions between Bartonella and Chlamydia species: implications for diagnosis. Journal of Clinical Microbiology. 35(9): 2283-2287.

MOGOLLON-PASAPERA, E., OTVOS JR, L. \& GIORDANO, A. 2009. Bartonella: emerging pathogen or emerging awareness? International Journal of Infectious Disease. 13:3-8.

MURINELlO, N., MURINELlO, A., DAMÁSIO, H., CARVALHO, A. \& SOUSA, R. 2010. Cat-Scratch disease in a 44-year-old woman. Revista Portuguesa de Doenças Infecciosas. 6(3):112-118.

OLIVEIRA, A.H.P., PEREIRA, C.A.P., SOUZA, L.B. \& FREITAS, D. 2004. Conjuntivite granulomatosa atípica causada pela doença da arranhadura do gato- Relato de caso. Arquivos Brasileiros de Oftalmologia. 67:541-543.

PONS, I., SANFELIU, I., QUESADA, M., ANTON, E., SAMPERE, M., FONT, B., PLA, J. \& SEGURA, F. 2005. Prevalence of Bartonella henselae in cats in Catalonia, Spain. The American Journal of Tropical Medicine and Hygiene. 72(4):453-457.

QUIMBY, J.M., ELSTON, T., HAWLEY, J., BREWER, M., MILLER, A. \& LAPPIN, M.R. 2008. Evaluation of the association of Bartonella species, feline herpesvirus 1, feline calicivirus, feline leukemia virus and feline immunodeficiency virus with chronic feline gingivostomatitis. Journal of Feline Medicine and Surgery. 10:66-72.

REGNERY, R.L., ANDERSON, B.E., CLARRIDGE, J.E., RODRIGUEZ-BARRADAS, M.C., JONES, D.C. \& CARR, J.H. 1992a. Characterization of a Novel Rochalimaea Species, $R$. henselae sp. nov., Isolated from Blood of a Febrile, Human Immunodeficiency VirusPositive Patient. Journal of Clinical Microbiology. 30(2):265-274.

REGNERY, R., MARTIN, M. \& OLSON, J. 1992b. Naturally occurring "Rochalimaea henselae" infection in domestic cat. Lancet. 340(8818):557-558.

REGNERY, R.L., ROONEY, J.A., JOHNSON, A.M., NESBY, S.L., MANZEWITSCH, P., BEAVER, K. \& 
OLSON, J.G. 1996. Experimentally induced Bartonella henselae infections followed by challenge exposure and antimicrobial therapy in cats. American Journal of Veterinary Research. 57(12):1714-1719.

REINE, N. J. 2004. Infection and blood transfusion: a guide to donor screening. Clinical Techniques in Small Animal Paractice. 19(2):68-74.

ROLAIN, J.M., BROUQUI, P., KOEHLER, J.E., MAGUINA, C., DOLAN, M.J. \& RAOULT, D. 2004. Recommendations for treatment of human infections caused by Bartonella species. Antimicrobial Agents and Chemotherapy. (48):1921-1933.

SANOGO, Y.O., ZEAITER, Z., CARUSO, G., MEROLA, F., SHPYNOV, S., BROUQUI, P. \& RAOULT, D. 2003. Bartonella henselae in Ixodes ricinus ticks (Acari: Ixodida) removed from humans, Belluno Province, Italy. Emerging Infectious Diseases. 9(3):329-332.

SOUZA, A.M., ALMEIDA, D.N.P., GUTERRES, A., GOMES, R., FAVACHO, A.R.M., MOREIRA, N.S., MAIA, L.M.P., ROZENTAL, T., FILHO, R.A.T., CERQUEIRA, A.M.F., LEMOS, E.R.S. \& ALMOSNY, N.R.P. 2010. Bartonelose: análise molecular e sorológica em gatos do Rio de Janeiro - Brasil. Revista Brasileira de Ciência Veterinária. 27(1):7-11.
SOUZA, G.F. 2011. Doença da arranhadura do gato: relato de caso. Revista Médica de Minas Gerais. 21(11):75-78.

STAGGEMEIR, R., VENKER, C.A., KLEIN, D.H., PETRI, M., SPILKI, F.R. \& CANTARELLI, V.V. 2010. Prevalence of Bartonella henselae and Bartonella clarridgeiae in cats in the south of Brazil: a molecular study. Memórias do Instituto Oswaldo Cruz. 105(7):873878.

STILES, J. 2011. Bartonellosis in cats: a role in uveitis? Veterinary Ophthalmology. 14(1):9-14.

VELHO, P.E.N.F., MORAES, A.M., SOUZA, E.M., UTHIDA-TANAKA, A.M. \& CINTRA, M.L. 2006. Diagnóstico da infecção por Bartonella spp.: a propósito de um caso de angiomatose bacilar. Anais Brasileiros de Dermatologia. 81(4):349-353.

WIEBE, V. 2002. Fluoroquinolone-induced retinal degeneration in cats. Journal of the American Veterinary Medical Association. 221(11):1568-1571.

ZANUTTO, M.S., MAMIZUCA, E.M., JÚNIOR, R.R., LIMA, T.M., DIOGO, C.L., OKAY, T.S. \& HAGIWARA, M.K. 2001. Experimental infection and horizontal transmission of Bartonella henselae in domestic cats. Revista do Instituto de Medicina Tropical de São Paulo. 43(5):257-261. 